\title{
Prevalence of allergenic arthropods in domestic dwellings of referrals to an asthma and allergy clinic in the Islamic Republic of Iran
}

Ayda Shafiei, ${ }^{1}$ Mohammad Djaefar Moemenbellah-Fard, ${ }^{2}$ Kourosh Azizi, ${ }^{2}$ Seyed Hesamedin Nabavizadeh, ${ }^{3}$ Tahere Dabaghmanesh ${ }^{1}$ and Aboozar Soltani ${ }^{2}$

${ }^{1}$ Department of Medical Entomology and Vector Control; ${ }^{2}$ Research Center for Health Sciences, Institute of Health, Department of Medical Entomology and Vector Control, School of Health; ${ }^{3}$ Allergy Research Center, Department of Paediatrics, Shiraz University of Medical Sciences, Shiraz, Islamic Republic of Iran (correspondence to: Aboozar Soltani: abu2sol@yahoo.com).

\begin{abstract}
Background: Allergenic arthropods are crucial agents in inducing medically important respiratory diseases like asthma and the inflammation of the respiratory tract worldwide.

Aims: This study was conducted to determine the prevalence of all arthropods in the dwellings of people referred to the asthma and allergy clinic in Shiraz.

Methods: This was was a cross-sectional descriptive study. Participants were 100 allergic patients who had tested positive (roach- and mite-sensitive). Mites were collected from their houses using a vacuum cleaner; other arthropods were caught with sticky traps. Direct observation and flotation methods were used and the samples were stored in $70 \%$ ethanol. Morphological characteristics were identified using valid taxonomic keys.

Results: Overall, 624 specimens were identified belonging to 14 orders (4 orders of mites: Astigmata, Cryptostigmata, Prostigmata and Mesostigmata; and 10 other arthropod orders: Diptera, Coleoptera, Hymenoptera, Thysanura, Thysanoptera, Entomobryomorpha, Blattodea, Siphonaptera, Pscoptera and Isopoda). The 2 most numerous species collected were Musca domestica and Dermanyssus gallinae.

Conclusion: A small number of dwellings were infested with cockroaches; none were infested with the common house dust mites. The allergies induced in these patients could likely be attributed to other arthropods that are not considered main allergens in asthma and allergy clinics in the Islamic Republic of Iran. Health surveillance and prevention of infestation for these arthropods could have an immense impact on the control of the allergenic arthropod community, prevention of respiratory diseases, and personal health in Shiraz.
\end{abstract}

Keywords: allergen, arthropod, asthma, allergy, indoor, urban

Citation: Shafiei A; Moemenbellah-Fard MD; Azizi K, Nabavizadeh SH; Dabaghmanesh T; Soltani A. Prevalence of allergenic arthropods in domestic dwellings of referrals to an asthma and allergy clinic in the Islamic Republic of Iran. East Mediterr Health J. 2020;26(5):586-593. https://doi. org/10.26719/emhj.19.087

Received: 23/05/18; accepted: 30/07/18

Copyright (C) World Health Organization (WHO) 2020. Open Access. Some rights reserved. This work is available under the CC BY-NC-SA 3.o IGO license (https://creativecommons.org/licenses/by-nc-sa/3.o/igo).

\section{Introduction}

\section{Background}

Over a million species of arthropods are reported in nature as having a significant role in the ecosystem; only a small fraction of these species are linked to human health. Arthropod vectors of infectious disease agents have special importance in the developing countries. They are also associated with certain allergic conditions and may induce or intensify some allergic reactions among humans $(1,2)$.

In sensitive people, asthma symptoms may be triggered by inhaling allergens. The triggers differ from person to person, most likely due to a combination of environmental and genetic factors. Common asthmacausing allergens include: arthropods (dust mites, cockroaches, etc.), animal hair or dander, dust, respired chemicals, mould, pollen and tobacco smoke (1).

House dust mites are widespread, tiny $(45-200 \mu \mathrm{m})$ arthropods belonging to the family Pyroglyphidae, order: Astigmata, class: Arachnida (3). These feed on skin relics, hair dandruff and other organic debris. They live and reproduce among clothes, bedding, carpets, furniture, household utilities and floors in human dwellings. The inhalation of faecal drops and protein moieties from the bodies of mites could cause allergic reactions like asthma, permanent allergic rhinitis and atopic dermatitis (eczema) among sensitive individuals $(4,5)$.

\section{Objectives}

Many other arthropods are also considered or identified as being allergenic such as cockroaches, house flies, mosquitoes, storage pests, biting insects, canine and feline fleas, butterfly larvae, bedbugs, horseflies, silverfish and non-biting midges (Chironomidae). These could cause various types of allergy in some people (6). Any plan to control and prevent the spread of these arthropods must be based on their proper identification and classification. This study was thus conducted to gain some insight on species diversity of these allergenic arthropods, their abundance and extent of distribution in Shiraz. 


\section{Methods}

\section{Study area}

This was a cross-sectional descriptive study conducted in Shiraz $\left(29^{\circ} 40^{\prime} \mathrm{N}, 52^{\circ} 33^{\prime} \mathrm{E}\right)$, the capital city of Fars province, Islamic Republic of Iran. It is located at about $1500 \mathrm{~m}$ above sea level. It has a subtropical, hot, semi-arid climate with a mean annual temperature of $18^{\circ} \mathrm{C}$, relative humidity of $41 \%$ and precipitation $337.8 \mathrm{~mm}$. Its hilly landscape is corrugated with the Zagros mountain range, which run northwest-southeast across the country.

\section{Patients}

In this investigation of all patients who were referred to the asthma and allergy clinic at Shiraz during the year of study, samplings were randomly carried out on the houses of 100 consenting patients who had positive skin tests to the Dermatophagoides farinae allergen, D. pteronyssinus allergen of house dust mites (D. farinae, D. pteronyssinus) and cockroach allergen. Samplings included patients' domiciles, in the particular loci which saw the highest frequency of inhabitants' activities. Participants were from both sexes with no age range limitation. After explaining the sampling procedure by an expert, informed consent forms were signed by all research participants or their parents (for children). In order to compensate for the possible drop-out of volunteers, sampling was continued until the sample size was completed.

\section{Allergic skin reaction tests}

Skin tests were done by the wheal and flare reactions on patients' forearms. Overall, 79 different items (comprising such categories as pollen, tree, grasses, weeds, mould, animals and food) were included in these tests, the reaction from each of which was observed directly on skin and the size of each reaction was measured and subsequently recorded. A drop of 50\% glycerin $+50 \%$ COCAS fluid (containing $\mathrm{NaCl} 0.5 \%, \mathrm{NaHCO}_{3} 0.0275 \%$, sterile water for injection, preservative $0.4 \%$ phenol) was used as negative control. A drop of standardized D. pteronyssinus, $5 \mathrm{~mL}$ in 10000 arbitrary units $/ \mathrm{mL}$ was used as the positive control. The negative control had a wheal and flare reaction of 1-3 units, while the positive control reaction measured $>3$ units. They were compared 20 minutes after the initial administration of the drops and their sizes measured and recorded accordingly.

\section{Sample size}

The sample size was calculated according to the following formula:

$$
n=\frac{\left(z_{1-\alpha}+z_{1-\beta}\right)^{2} p_{0} q_{0}}{\left(p_{1}-p_{0}\right)^{2}}
$$

\section{Sample size calculation for estimating a proportion p1}

\begin{tabular}{llllll} 
Power & z-score & Precision & Variance & $\mathrm{p} 1$ & $\mathrm{p} 1 \times(1-\mathrm{p} 1)$ \\
0.8 & 1.96 & 0.11 & 0.16 & 0.2 & 0.8 \\
Sample size & 100.7286 & & & & \\
\hline
\end{tabular}

\section{Study design}

At each house, samples were collected from different points using sticky traps or a vacuum cleaner to collect indoor arthropods. In the latter case, the content from each round of sampling (each $1 \mathrm{~m}^{2}$ in 1 minute) was emptied into a plastic freezer bag, labelled (collection place, relative humidity, ambient temperature, etc.) and frozen for later examination and identification in the laboratory. Sticky traps were fixed in different places and collected 24 hours later. The next day at the laboratory, equal weights of $200 \mathrm{mg}$ portions from house dust samples were transferred into medium sized Petri dishes (minimum 5 times) and directly observed under a binocular microscope. Mites, being sensitive to light more slowly, were picked up and separated using the fine damp tip of entomological needle. They were then mounted onto microscope slides for further examination. Using diagnostic morphological features and valid taxonomic keys, they were identified to species level (3).

\section{Statistical analysis}

The collated data were uploaded onto the PC and analysed descriptively (frequencies and other descriptive statistics). We used SPSS, version 19, and Excel to tabulate results and draw histograms.

\section{Results}

A total of 624 specimens of arthropods were collected from the houses of 100 patients referred to the asthma and allergy clinic; these houses were located in various parts of Shiraz. From these, 46 mites and 578 other arthropods were identified. Table 1 shows the abundance order distribution of arthropods gathered from houses of patients referred to the asthma and allergy clinic. The species diversity in the insect orders and families was greater than in the class Arachnida. The specimens were classified into 14 orders based on their major morphological features. In the largest insect order, Coleoptera, 3 families, including 4 genera and 5 species, were identified (Table 1). In the medically important order Diptera, 4 families, including 4 species, were identified. Active search for arthropods using the vacuum cleaner method yielded a higher number of arthropod species (25 vs 16) than by the passive sticky trap collection method. The 2 most numerous species collected from patients' houses were Musca domestica and Dermanyssus gallinae. A total of 226 dipteran flies (129 M. domestica, 81 Telmatoscopus proximus, 11 Chrysomya albiceps, and 5 Sarcodexia lambens) were trapped from $7 \%, 20 \%, 3 \%$ and $2 \%$ of human residences, respectively (Table 1).

The moth fly, T. proximus, whose infestation by house was the highest among all Diptera (20\%) (Figure 1), has a pair of dichoptic eyes, clear venation on tapered wings, and 16-segmented digitiform antennae, each segment of which is proximally barrel-shaped and equipped with multiple rings of unbranched sensory filaments or ascoid setae. This species is common in houses of Shiraz but is not considered an important allergenic arthropod by physicians or members of the health system. However, 


\begin{tabular}{|c|c|c|c|c|c|c|c|}
\hline Class & Family & Genus & Species & Common name & No. trapped & $\begin{array}{c}\text { Abundance } \\
(\%)\end{array}$ & $\begin{array}{c}\text { How } \\
\text { collected }\end{array}$ \\
\hline \multicolumn{8}{|l|}{ Insecta } \\
\hline \multirow[t]{2}{*}{ Collembola } & Entomobryidae & Entomobrya & multifasciata & Spring tail & 45 & 90 & VC \\
\hline & & & nicoletti & Spring tail & 5 & 10 & VC \\
\hline \multirow[t]{5}{*}{ Coleoptera } & Tenebrionidae & Tribolium & castaneum & Red flour beetle & 28 & 36.36 & $\mathrm{VC} / \mathrm{ST}$ \\
\hline & & & confusum & Confused flour beetle & 10 & 13 & $\mathrm{VC} / \mathrm{ST}$ \\
\hline & & Dichillus & Unidentified & Darkling beetle & 8 & 10.38 & $\mathrm{VC}$ \\
\hline & Cucujiidae & Oryzaephilus & surinamensis & $\begin{array}{l}\text { Saw-toothed grain } \\
\text { beetle }\end{array}$ & 4 & 5.19 & $\mathrm{VC} / \mathrm{ST}$ \\
\hline & Dermestidae & Anthrenus & museorum & Museum/skin beetle & $5 / 22$ & 35.07 & $\mathrm{VC} / \mathrm{ST}$ \\
\hline \multirow[t]{3}{*}{ Hymenoptera } & Formicidae & Myrmica & sabuleti & Sand ant & 97 & 92.38 & $\mathrm{VC} / \mathrm{ST}$ \\
\hline & Vespidae & Vespula & macalifrons & Eastern yellow jacket & 2 & 1.91 & ST \\
\hline & & Polistes & gallicus & Paper wasp & 6 & 5.71 & ST \\
\hline \multirow[t]{4}{*}{ Diptera } & Muscidae & Musca & domestica & House fly & 129 & 57.07 & ST \\
\hline & Calliphoridae & Chrysomya & albiceps & Blow fly & 11 & 4.87 & ST \\
\hline & Sarcophagidae & Sarcodexia & lambens & Flesh fly & 5 & 2.22 & ST \\
\hline & Psychodidae & Telmatoscopus & proximus & Moth fly & 81 & 35.84 & ST \\
\hline \multirow[t]{2}{*}{ Blattodea } & Blattidae & Periplaneta & americana & American cockroach & 12 & 43.55 & ST \\
\hline & Blatellidae & Blatella & germanica & German cockroach & 20 & 56.45 & ST \\
\hline Thysanura & Lepismatidae & Lepisma & saccharina & Silver fish & 15 & 100 & VC \\
\hline Thysanoptera & Thripidae & Frankliniella & tritici & Flower thrips & 16 & 100 & VC \\
\hline Siphonaptera & Pulicidae & Pulex & irritans & Human flea & 1 & 100 & ST \\
\hline Psocoptera & Liposcelididae & Liposcelis & paetus & Book louse & 10 & 100 & $\mathrm{VC} / \mathrm{ST}$ \\
\hline \multicolumn{8}{|l|}{ Malacostraca } \\
\hline Isopoda & Cylisticidae & Cylisticus & convexus & Wood louse & 16 & 100 & $\mathrm{VC} / \mathrm{ST}$ \\
\hline \multicolumn{8}{|l|}{$\begin{array}{l}\text { Arachnida: } \\
\text { Acarid mites }\end{array}$} \\
\hline \multirow[t]{2}{*}{ Astigmata } & Glycyphagidae & Glycyphagus & prunorum & Cheese mite & 1 & 25 & VC \\
\hline & Suidasiidae & Suidasia & nesbitti & Scaly grain mite & 3 & 75 & VC \\
\hline Cryptostigmata & Oppiidae & Aeroppia & SU & Oribatid mite & 5 & 100 & $\mathrm{VC}$ \\
\hline Prostigmata & Bdellidae & Cyta & latirostris & Predator mite & 1 & 100 & $\mathrm{VC}$ \\
\hline \multirow[t]{9}{*}{ Mesostigmata } & Laelaptidae & Haemolaelaps & glasgowi & Common rodent mite & 3 & 8.33 & VC \\
\hline & & Echinolaelaps & echidninus & Spiny rat mite & 4 & 11.11 & VC \\
\hline & & Laelaps & nuttalli & Domestic rat mite & 3 & 8.33 & VC \\
\hline & Dermanyssidae & Dermanyssus & gallinae & Red fowl mite & 13 & 36.15 & VC \\
\hline & & & americanus & American bird mite & 6 & 16.66 & VC \\
\hline & Macronyssidae & Ornithonyssus & bursa & Tropical bird mite & 3 & 8.33 & $\mathrm{VC}$ \\
\hline & & & sylviarum & Northern fowl mite & 2 & 5.55 & $\mathrm{VC}$ \\
\hline & Ascidae & Blattisocius & tarsalis & Egg eating mite & 1 & 2.77 & VC \\
\hline & Parasitidae & Holoparasitus & Unidentified & Gamasid mite & 1 & 2.77 & VC \\
\hline
\end{tabular}

VC = vacuum cleaner ST $=$ sticky trap.

their hair and other part of their body could be allergenic to human.

The most numerous $(n=97)$ insect species found in patients' dwellings was the sand ant, Myrmica sabuleti, which was found in $24 \%$ of all infested houses (Figure 2). The second and third most frequent insect groups were the moth flies (mostly in suburban areas) and cockroaches (mostly in urban areas), being caught in $20 \%$ and $15 \%$ of all infested houses, respectively (Figure 1). All of the other insect species collected from patients' houses had infestation levels $\leq 10 \%$.

The infestation frequencies of mites were more homogeneously restricted than insects, ranging from $1 \%$ to $5 \%$, with the 2 species of red poultry mites ( 13 


\section{Figure 1 Distribution of infestations of dipterans, fleas and cockroaches in allergic patients' dwellings $(n=100)$ in Shiraz, 2016}

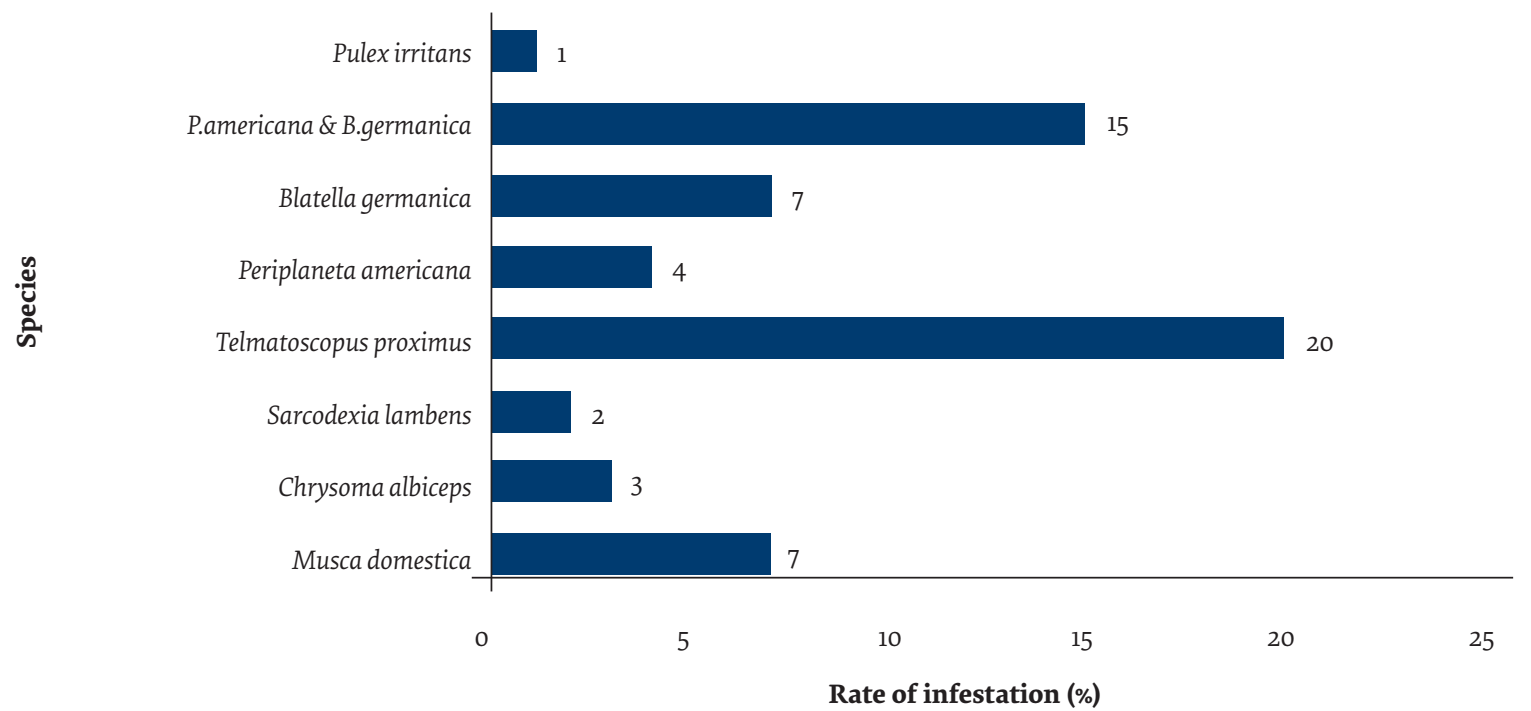

Dermanyssus gallinae and 6 D. americanus) being found in $5 \%$ of infested houses (Figure 3 ). The red poultry mite, $D$. gallinae, also had the highest rate $(36.15 \%)$ of abundance among the mesostigmatid mites (Figure 4).

\section{Discussion and conclusion}

Our findings showed that all (100\%) patients' dwellings were infested with at least one allergenic arthropod group. Generally, simultaneous multiple infestation of the dwellings of allergic human is the rule. Within the Arachnida, the cosmopolitan mesostigmatid red poultry mite, D.gallinae, represents a domestic and occupational allergenic species reported mostly from indoors in birds' nests. The allergenic character of this mite has been confirmed through clinical evidence as well as from purification and sequencing of amino acids in allergens. In 1970, Bernecker reported that $2 \%$ of individuals who were positive to the allergic dermal test from $D$. pteronyssinus were also positive to D. gallinae. The concept of immunological cross-reactivity from skin prick tests between these 2 different arthropod species should not be ignored. Allergic signs are thus indicated which could be induced by the bites of the red poultry mite. From this species, a tropomyosin allergen belonging to the group 10 allergens $(D$. gallinae allergen) has been isolated, cloned and sequenced (7). Cases of human infestation with this species were

Figure 2 Distribution of infestations of non-dipteran insects found in allergic patients' dwellings ( $n=100)$ in Shiraz, 2016

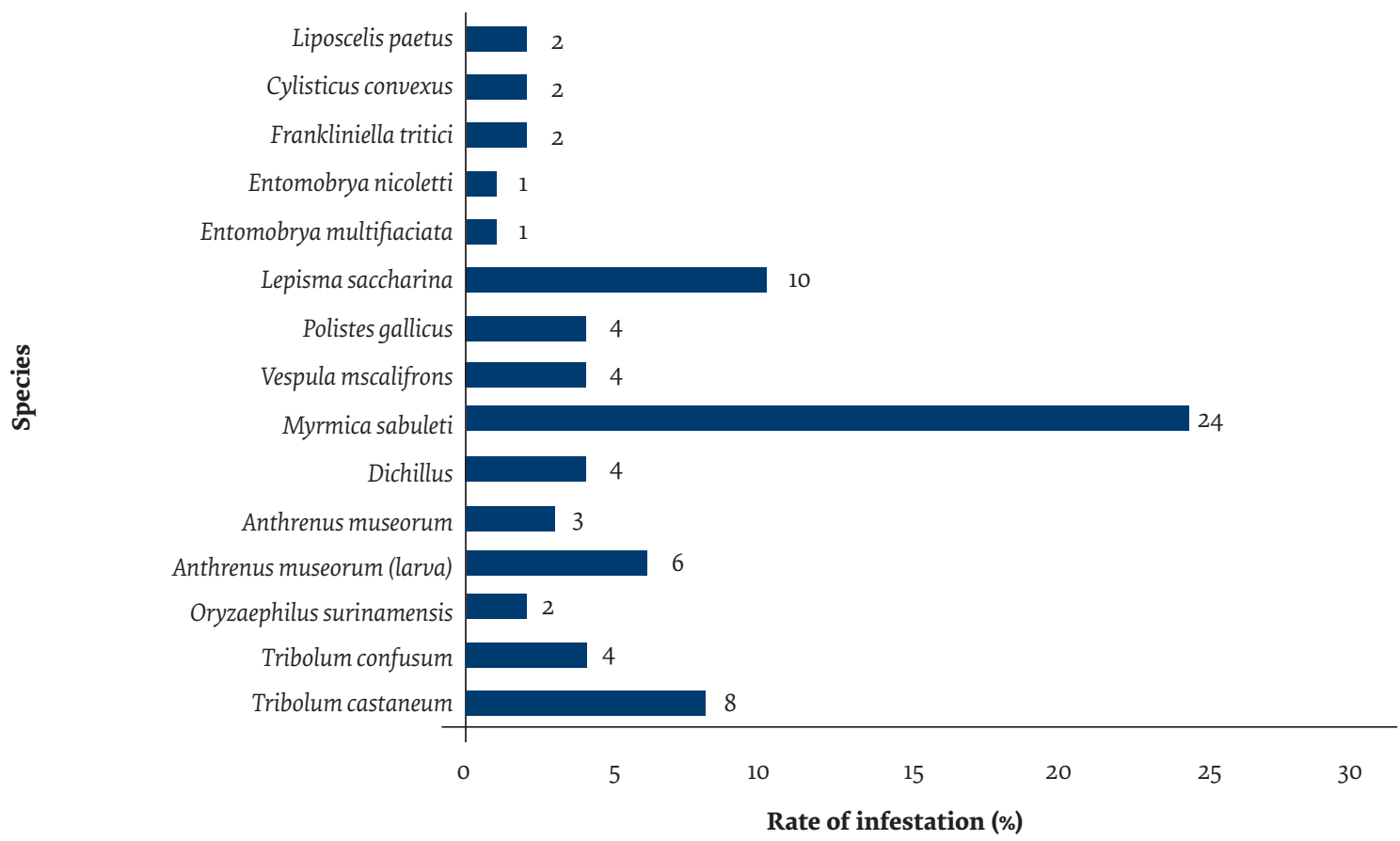


Figure 3 Distribution of all mites found in allergic patients' dwellings $(n=100)$ in Shiraz, 2016

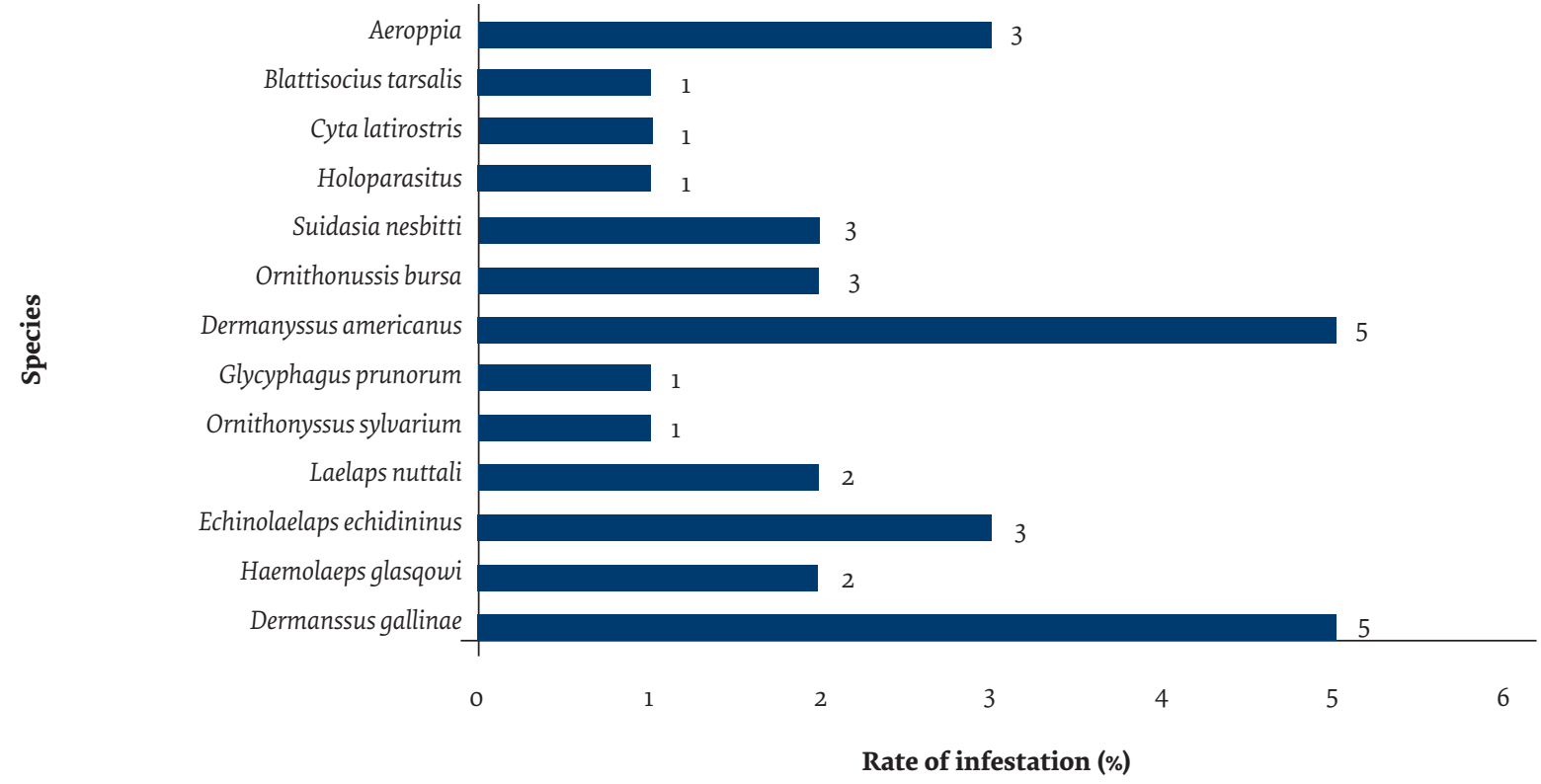

first reported in the Islamic Republic of Iran in 2014 (8). Some encephalitis viruses have been reported from this species, which is an indication of their medical importance. This species can also feed on humans, other mammals and birds and cause dermatitis and skin lesions. Cases of human infestation with D. gallinae are reported from Britain, Denmark, Egypt, France, Holland, Japan, Monte Negro, Morocco, Norway, Serbia and Turkey (9).

Isolation of the common rat house mite, Haemolaelaps glasgowi, from human dwellings could be attributed to the population eruption of urban rats infiltrating human dwellings in recent years. No routine antigenic tests are currently done for rat mites in this part of the world. Two other bird mites, Ornithonyssus sylviarum and O. bursa, which are often found among feathers, once on a human host could induce itching and painful dermatitis due to long allergic reactions. Some encephalitis viruses have been isolated from these 2 mites (10).

Description of H. glasgowi was first reported as the most widespread rodent ectoparasite in the Islamic Republic of Iran almost 2 decades ago (11). Both this species and 0 . sylviarum were subsequently identified from rodents in the city of Khoramabad in the west of the country (12). The latter species, the northern fowl mite,

Figure 4 Frequency of different species of mesostigmatid mites found in allergic patients' dwellings, Shiraz, 2016

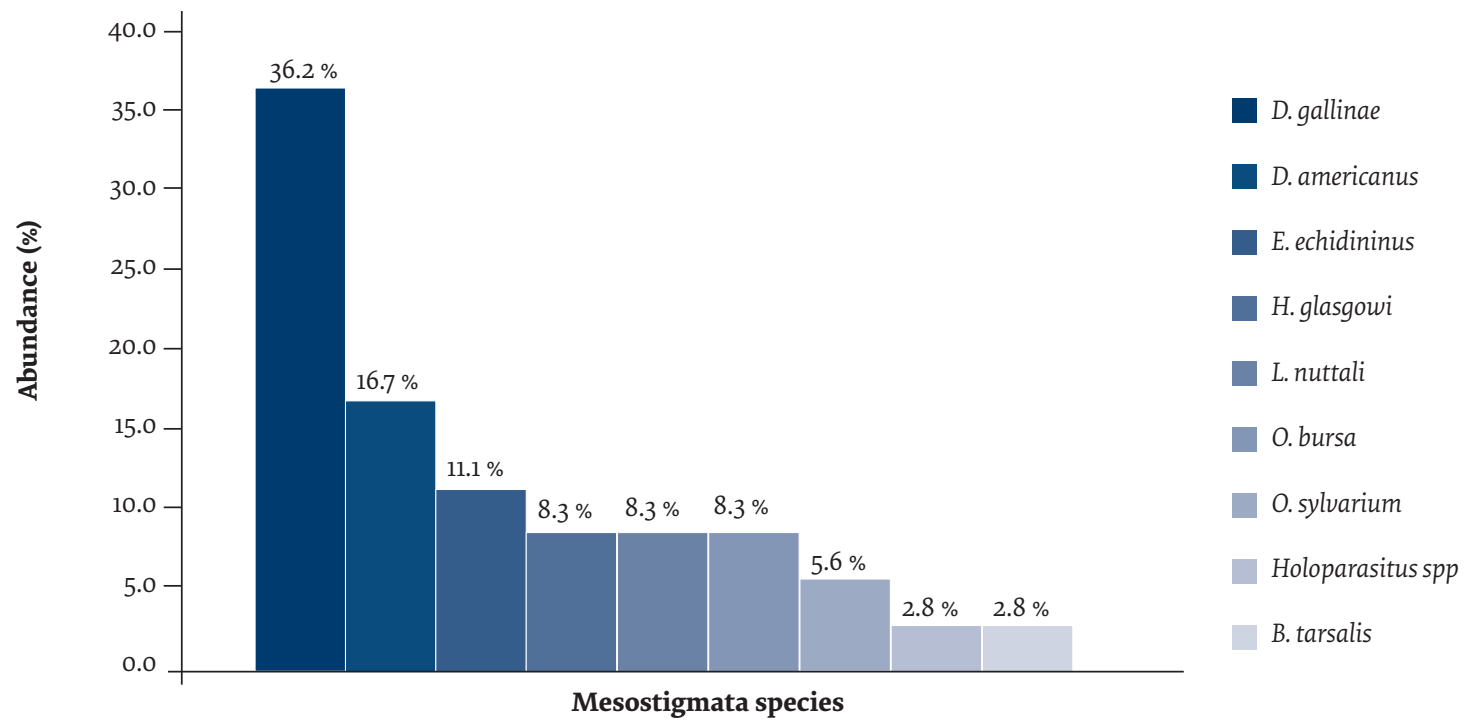


was recently described in sparrows in the west (13). The presence of these species was likely due to the breeding of either birds or rodents in human settlements in Shiraz.

The identification and medical importance of 3 other species of mesostigmatid mites, Dermanyssus americanus, Laelaps nuttalli, and Echinolaelaps echidninus, has been established in the Islamic Republic of Iran. All these species were reported as ectoparasites in a rodent control programme in the southern port city of Bandar-Abbas (14). The first of these, the American red poultry mite, often lives on birds. It can cause eczematous dermatitis in some individuals (15).

Only 2 species were found from the astigmatid mites, Suidasia nesbitti and Glycyphagus prunorum. Both of these have medical importance and could induce cross-reactivity with other allergenic mites. In addition, ingestion of foods infested with $S$. nesbitti could induce anaphylaxis in susceptible individuals (16). This species is known to be one of the group 2 allergen inducers. The cheese mite, G. prunorum, induces intense itching and pruritus by penetration into the fissures of the epidermal layers of foot, hand and face. It is most often found on workers in cereal, flour and vegetable storage facilities (17). This genus is considered to be a storage products and dust mite. Its allergens have been identified using the skin radioallergosorbent test (RAST), purification and amino acid sequencing. Cross-reactivity between this, storage, and house dust mites has previously been verified (18).

From the hexapods, beetles, including Tribolium confusum, were found, which are associated with rhinitis, conjunctivitis, wheal and signs of asthma in some individuals (19). The beetle genus Dichillus was first reported from Turkey in 2012 (20). No medical importance has so far been recorded for this genus.

From the order Hymenoptera, the sand ant, Myrmica sabuleti, was the most abundant species among the nondipteran hexapods. In addition to fire ants, Solenopsis, other genera of ants like Formica and Myrmica could induce serious allergic reactions in people (21). The species Vespula maculifrons, the eastern yellow jacket, is of medical importance but has not been reported from the Islamic Republic of Iran so far.

The order Diptera includes house flies, Musca domestica being the most frequently captured insect in allergic patients' dwellings. Their medical significance is evidently recorded. This and a number of other flies are also implicated in forensic medicine. The flesh fly, Sarcodexia lambens, may be involved in myiasis (22). Allergic reactions and asthma, particularly among children, may result from dried faeces, somatic setae, secretions and saliva from these species of flies in the vicinity of victims (19).

Steam bugs, including German and American roaches, Blatella germanica and Periplaneta americana, are 2 of the primary sources of allergens indoors inducing asthma and allergic reactions in susceptible individuals (23). The allergenic role and clinical importance of roaches on Iranian children with asthma has previously been investigated (24).

At present, studies on the allergic skin reaction test, which is routinely implemented in relation to allergenic arthropods at asthma and allergy clinics, is restricted to house dust mites (D. farinae and D. pteronyssinus) and cockroaches. Data from our investigation show that although all individuals whose houses were explored for the presence of arthropods were positive for the allergic skin reaction test, our findings indicate that only $15 \%$ of dwellings were infested with roaches and none of them were infested with the common house dust mites. Considering the fact that most arthropods can crossreact with other allergenic species, the allergies induced in these people could likely be attributed to other less important arthropods. It is thus suggested that, in line with routine tests, certain standard tests be carried out with regard to other allergenic arthropods so that the main disease-causing agent can be identified and suitable control measures can be included in an integrated control programme for training patients.

Finally, since a number of parasitic and vector-borne diseases are endemic to our region, the collection of data on the numerous prevalent arthropods is beneficial to the planning and evaluation of control measures to reduce disease. In conclusion, it is suggested that in all of the patients' dwellings, infestation with a minimal number of allergenic arthropod species are evidently observed. Health surveillance and prevention of infestation with these arthropods could have an immense impact on the control of the allergenic arthropod community, the prevention of respiratory diseases, and personal health care.

\section{Acknowledgements}

The authors are grateful for the assistance of the Vice-Chancellorship for Research and Technology at Shiraz University of Medical Sciences and to Mr H. Karami for his vigilant technical support.

Funding: This paper has partly been derived from, and supported by, the MSc thesis of Ms Ayda Shafiei (Grant No: 947574 dated 11 September 2015) in Medical Entomology, at the School of Health, Shiraz University of Medical Sciences, Islamic Republic of Iran.

Competing interests: None declared. 


\section{Prévalence des arthropodes responsables de manifestations allergiques dans les habitations de patients orientés vers un centre spécialisé pour la prise en charge de l'asthme et des allergies en République islamique d'Iran \\ Résumé}

Contexte: Les arthropodes responsables de manifestations allergiques sont des vecteurs fondamentaux de maladies respiratoires sévères comme l'asthme et l'inflammation des voies respiratoires partout dans le monde.

Objectifs : La présente étude a été menée pour déterminer la prévalence de tous les arthropodes dans les habitations de patients orientés vers le centre spécialisé pour la prise en charge de l'asthme et des allergies à Chiraz.

Méthodes : Une étude transversale descriptive a été menée. Les participants étaient 100 patients allergiques ayant eu des tests positifs (sensibilité aux cafards et aux acariens). Des acariens ont été prélevés dans leurs habitations à l'aide d'un aspirateur. Les autres arthropodes ont été attrapés au moyen de pièges adhésifs. Les méthodes de l'observation directe et de la flottation ont été employées, et les échantillons ont été placés dans de l'éthanol à $70 \%$. Les caractéristiques morphologiques ont été identifiées en utilisant des clés taxonomiques valides.

Résultats : En tout, 624 échantillons ont été identifiés. Ils appartenaient à 14 ordres (4 ordres d'acariens : Astigmata, Cryptostigmata, Prostigmata et Mesostigmata; et 10 autres ordres d'arthropodes : Diptera, Coleoptera, Hymenoptera, Thysanura, Thysanoptera, Entomobryomorpha, Blattodea, Siphonaptera, Pscoptera et Isopoda). Les deux espèces les plus représentées parmi les échantillons étaient Musca domestica et Dermanyssus gallinae.

Conclusions : Un petit nombre d'habitations étaient infestées par les cafards. Aucune n'était infestée par les acariens de poussière de maison. Les allergies induites chez ces patients pourraient probablement être attribuées à d'autres arthropodes non considérés comme des allergènes majeurs dans les centres spécialisés pour la prise en charge de l'asthme et des allergies en République islamique d'Iran. La surveillance de santé et la prévention des infestations par ces arthropodes pourraient avoir un énorme impact sur le contrôle de la communauté d'arthropodes responsables de manifestations allergiques, la prévention des maladies respiratoires et la santé personnelle à Chiraz.

$$
\begin{aligned}
& \text { معدل انشار المفصليات الـمُسبية للحساسية في مساكن المحالين إلى عيادات الربو والحساسية في جمهورية إيران الإسامية } \\
& \text { آيدا شفيعي، محمد جعفر مؤمن بالله فرد، كوروش عزيزي، سيد حسام الدين نبوي زاده، طاهره دباغ منش، أبو ذر سلطاني }
\end{aligned}
$$

الخلفية: تُعدُّ المفصليّات المسببة للحساسية عو امل أساسية تؤدي إلى استثارة أمراض تنفسية ذات أهمية طبية في العالم كله، كالربو و التهاب الجهاز

$$
\text { الأهداف: هدفت هذه الدراسة إلى تحديد معدل انتشار المفصليات في مساكن الأشخاص المحالين إلى عيادات الربو والحساسية في شيراز. }
$$

طرق البحث: كانت هذه الدراسة وصفية ومقطعية. وكان المشاركون فيها 100 من المرضى المصابين بالحساسية من جاءت نتيجة اختبارهم إيبابية

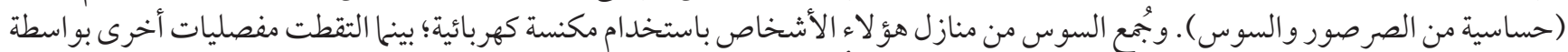

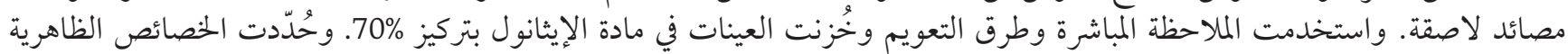

$$
\text { باستخدام مفاتيح تصنيفية صحيحة. }
$$

النتائج: بصورة عامة، حُدّدت 624 عينة تنتمي إلى 14 رُتبة (4 رُتب للسوس، وهي: الحمكيات، و القراضيات الخنفسية، وأماميات الفوهة،

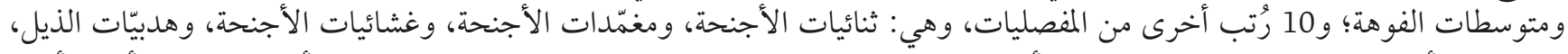

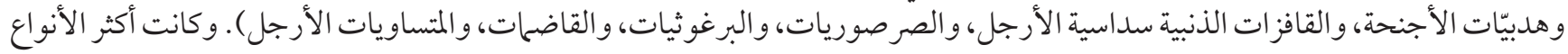

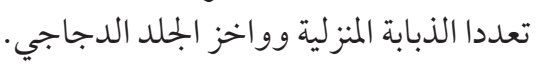

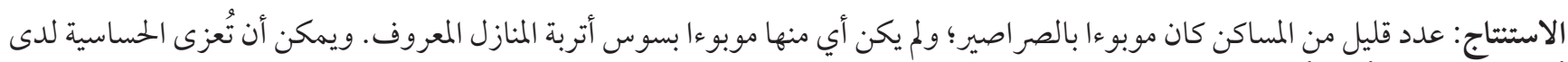

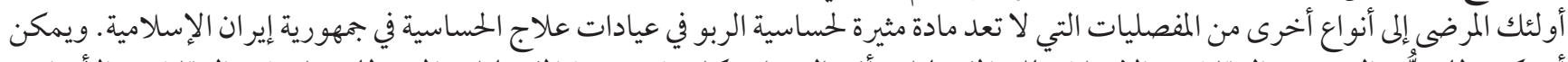

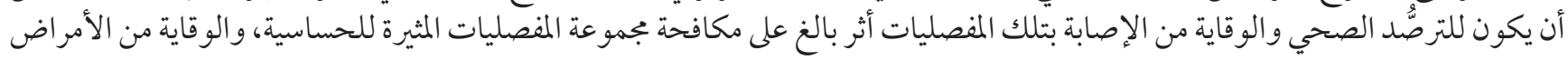

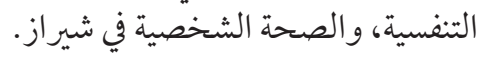




\section{References}

1. Jeong KY, Hong CS, Yong TS. Domestic arthropods and their allergens. Protein Pept Lett. 2007 Oct 1;14(10):934-42. PMID:18220990

2. Linneberg A. Are we getting enough allergens? Int Arch Allergy Appl Immunol. 2008 Jun 3;147(2):93-100. doi:10.1159/000135695

3. Service MW. Medical entomology for students, 3rd ed. Cambridge: Cambridge University Press; 2004.

4. Wang DY. Risk factors of allergic rhinitis: genetic or environmental. Ther Clin Risk Manag. 2005 Jun;1(2):115-23. PMID:18360551

5. Soltani A, Azizi K, Saleh V, Dabaghmanesh T. The fauna and distribution of house dust mites in residential homes of Bandar Abbas District, Southern Iran. Exp Appl Acarol. 2011 Jul 1;54(3):269-76. doi:10.1007/s10493-011-9436-6

6. Arlian LG. Arthropod allergens and human health. Annu Rev Entomol. 2002 Jan;47(1):395-433. PMID:11729080

7. Nisbet AJ, Huntley JF, Mackellar A, Sparks N, McDevitt R. A house dust mite allergen homologue from poultry red mite Dermanyssus gallinae (De Geer). Parasite Immunol. 2006 Aug 1;28(8):401-5. doi:10.1111/j.1365-3024.2006.00862.x

8. Abdigoudarzi M, Mirafzali MS, Belgheiszadeh H. Human infestation with Dermanyssus gallinae (Acari: Dermanyssidae) in a family referred with pruritus and skin lesions. Iran J Arthropod Borne Dis. 2014 Jun 1;8(1):119. PMID:25629073

9. Dogramaci AC, Culha G, Özçelik S. Dermanyssus gallinae infestation: an unusual cause of scalp pruritus treated with permethrin shampoo. J Dermatolog Treat. 2010 Sep;21(5):319-21. doi:10.3109/09546630903287437

10. Colloff MJ. Dust mites. Dordrecht: Springer; 2009. doi:10.1007/978-90-481-2224-0

11. Bochkov A, Arbobi M, Malikov V. Notes on mites of the family Myobiidae (Acari: Prostigmata) parasitising rodents (Mammalia: Rodentia) in Iran. Folia Parasitol. 2000 Jan 1;47(1):73-7. PMID:10833020

12. Shayan A, Rafinejad J. Arthropod parasites of rodents in Khorram Abbad district, Lorestan Provincen of Iran. Iran J Public Health. 2006;35(3):70-6.

13. Moodi B, Aliabadian M, Moshaverinia A, Kakhki OM, Faraji F. Mites associated with passerine birds in eastern Iran. Int J Acarology. 2014 Feb 17;40(2):133-7. doi:10.1080/01647954.2014.888094

14. Hanafi-Bojd AA, Shahi M, Baghaii M, Shayeghi M, Razmand N, Pakari A. A study on rodent ectoparasites in Bandar Abbas: the main economic southern seaport of Iran. Iran J Environ Health Sci Eng. 2007;4(3):173-6.

15. George DR, Finn RD, Graham KM, Mul MF, Maurer V, Moro CV, et al. Should the poultry red mite Dermanyssus gallinae be of wider concern for veterinary and medical science?. Parasit Vectors. 2015 Mar 25;8(1):1. doi:10.1186/s13071-015-0768-7

16. Dutau G. House dust mites: new food allergens. Rev Francaise d'Allergologie et d'Immunologie Clinique. 2002 Mar 1;42(2):171-7.

17. Steen CJ, Carbonaro PA, Schwartz RA. Arthropods in dermatology. J Am Acad Dermatol. 2004 Jun 30;50(6):819-42. doi:10.1016/j. jaad.2003.12.019

18. Mumcuoglu Y. House dust mites in Switzerland: II. culture and control. Int J Acarol. 1977 Jun 1;3(1):19-25. PMID:1162310

19. Arlian LG. Arthropod allergens and human health. Annu Rev Entomol. 2002 Jan;47(1):395-433. PMID:11729080

20. Canpolat D, Hasbenli A. New records of Tenebrioninae and Pimeliinae (Coleoptera: Tenebrionidae) from Turkey. J Entomol Res Soc. 2012 Jan 1;14(1):15-20.

21. Horton SM. Identifying the locations, movement and habitat of the European fire ant, Myrmica rubra: an invasive species in the urban/suburban environment of Halifax, Nova Scotia [thesis]. Halifax: Saint Mary's University; 2012.

22. Bermúdez C, Buenaventura R, Couri M, Miranda RJ, Herrera JM. Mixed myiasis by Philornis glaucinis (Diptera: Muscidae), Sarcodexia lambens (Diptera: Sarcophagidae) and Lucilia eximia (Diptera: Calliphoridae) in Ramphocelus dimidiatus (Aves: Thraupidae) chicks in Panama. Bol Soc Entomol Aragon. 2010(47):445-6.

23. Mollet JA, Vailes LD, Avner DB, Perzanowski MS, Arruda LK, Chapman MD, et al. Evaluation of German cockroach (Orthoptera: Blattellidae) allergen and seasonal variation in low-income housing. J Med Entomol. 1997 May 1;34(3):307-11. doi:10.1093/jmedent $/ 34.3 .307$

24. Farhoudi A, Pourpak Z, Mesdaghi M, Chavoshzadeh Z, Kazemnejad A. The study of cockroach allergy in Iranian children with asthma. Iran J Med Sci. 2015 Nov 30;27(4):156-60. 